\title{
Technology Leadership of Education Administers and Innovative Technologies in Education: A Case Study of Çorum City ${ }^{*}$
}

\author{
Hakan Kör ${ }^{1}$, Hasan Erbay ${ }^{2, *}$, Melih Engin ${ }^{3}$ \\ ${ }^{1}$ Distance Education Center, University of Hitit, 19030, Çorum, Turkey \\ ${ }^{2}$ Faculty of Engineering, Computer Engineering, University of Kırıkkale, Yahşihan, 71450, Kırıkkale, Turkey \\ ${ }^{3}$ İnegöl Faculty of Business, Management Information Systems, University of Uludağ, İnegöl, 16400, Bursa, Turkey \\ *Corresponding Author: hxe68@yahoo.com
}

Copyright $\bigcirc 2016$ by authors, all rights reserved. Authors agree that this article remains permanently open access under the terms of the Creative Commons Attribution License 4.0 International License

\begin{abstract}
In this global world in which educational technologies have developed at such a great pace, it is possible to say that administrators in the education sector are obliged with serious roles with regard to keeping up with the evolving technology and the management of education in this virtual environment. In the present study utilizing screening research method, technologic leadership attitudes of administrations in educational domain were investigated. The survey titled "Technology Leadership of Education Administers" developed by Banoğlu [24] was employed in this study. The research universe consisted of administers at the public schools located in Çorum City. The research sampling was composed of 161 school administers who participated in the "Technology Leadership of Education Administers" survey on a volunteer basis. The acquired data was analyzed through the SSPS 22 package software with descriptive and comparative statistical methods. The analysis results were presented in the tables in the findings section.
\end{abstract}

Keywords Technology Leadership, Technology Leadership of Education Administers, Innovative Technologies in Education Ship

\section{Introduction}

Today technology is constantly developing, used in every field of life and causing various changes. It is not likely that education-teaching activities will not be affected by technological developments. Studies have revealed that educating-teaching and administration activities are carried out more rapidly and safely thanks to technology. Also, students and parents' expectations from schools and the education systems are increasing. Students and parents want technological devices to be used in an educational setting to receive more quality education. In this context, the importance of technology is boosted and it is a must to use technology in educating-teaching activities.

Many definitions of technology have been made in different ways in the literature. Technology was defined by the International Technology Education Association (ITEA, 2007) as changing, modernize and converting the natural setting to satisfy perceived human needs and requests. The ITEA (2007) stated that learners can gain technology literacy with the help of education [1]. This statement requires teachers to be technology literate [2].

Technology is a motivator in terms of students' individual learning needs and styles. Learning occurs better when students work in groups using technology.

The Colorado Department of Education (CDE) defines technology literacy as the competency to;

- communicate,

- solve problems,

- have access to, design, integrate, evaluate and manage information,

- acquire lifelong information and skills in the $21 \mathrm{st}$ century [3].

In studies carried out by the International Technology Education Association in the US, technology literacy is defined as "an individual who knows what technology is, how it emerged, how it shapes society, and how society shapes it" [1]. In other words, technologically literate individual inquires technological processes and innovations critically. The individual who has a critical point of view towards technology is intellectual enough to understand the benefits and damages of every technological development and to analyze the political and social effects that can accelerate or slow down its cost and development, and thus will have the opportunity to affect her/his environment and shape her/his future [4][5].

James Finn, a famous education technologist, defines technology as follows: 'Besides using machinery, technology is the point of view that will create solutions 
appropriate with problems' degree of difficulty, technical solution possibilities, and economical values for problems stemming from both humans and things using systems, operations, management, and control mechanisms [6].

Technology is a significant part of directing discoveries by making use of data sharing most effectively [7]. According to Volti, technology is a system that produces objects and techniques by using information and organization to reach certain targets. Also, technology is the devices and techniques developed and applied by humans; thanks to technology humanity has done many hard to do things thought hard to achieve [8]. According to Simon, technology is a rational discipline designed to dominate the physical nature by implementing scientifically-defined laws. According to McDermott [9], technology is a rational system through which a few technically qualified individuals control big masses, daily events, and machines in an organized way [10].

Özkul and Girginer pointed out the following reasons for using technology in education [11]:

- Increasing access to education and teaching

- Increasing the quality of teaching

- Decreasing education costs

- Adapting to technological changes

- Students gaining skills they will need in their work lives and private lives.

Some researchers believe that more use of technology in education will increase education opportunities and its quality [12]. Based on this basic assumption, many projects are done and applied to extend and use technological devices effectively in schools in Turkey by the Ministry of National Education (MNE). Projects such as the Basic Education Project, Developing National Education Project, Computer-Assisted Education Project, Industrial Schools Projects, Non-formal Vocational Training Project, Catch the Era 2001 Project, World Links Project, Education Portal, Access to Information Portal, Skoool.tr, Think.com Portal, Intel Teacher Program, Intel Student Program, Innovative Teachers Projects, Ministry of National Education Information System (MEBBİS), e-In-service Training, e-Transportable Project, and e-School Projects are applied by the Ministry of National Education and are related to technologies known as education and information technologies.

In line with the developments in information technologies in the 2000s, school administers have been faced with demands such as purchasing information equipment for schools, appointing a full-time or part-time IT specialist in schools, and training teachers to use new technological devices [13]. Some studies have been done with respect to how effectively these technologies are used and what kind of problems emerge after investments in using technology has been done. The cost of and investing in integrating technology with school systems have brought on questions about the effectiveness of technology in schools [13] [14]. It has been pointed out that many schools are not aware of the benefits of education technologies despite spending huge amounts for purchasing these technologies. Schrum [15] stated that although there were computer-assisted education software, distance learning and smart boards in schools, their effect on school reform is limited. Studies carried out in developing countries to reveal the state of school administers' benefiting from education technologies revealed that many headmasters had little information and few skills, and were rather incompetent [16].

Weber [14] indicated that the biggest problem in terms of using education technologies stemmed from unprepared headmasters and that headmasters should direct teachers with respect to effective use of technology. Based on these studies, it can be said that headmasters are one of the most significant element affecting the use of education technologies in schools. It can also be said that headmasters are not trained well enough regarding their leadership of using education technologies during their pre-service and in-service trainings; however, they are becoming more and more responsible for using education technologies in schools.

\section{Literature}

Şişman-Eren [17] specified that headmasters' technology leadership behaviors did not differ by gender, branch, educational status, time passed after graduation, professional seniority, seniority in working as a headmaster, and region they worked, but it differed by trainings they received. Moreover, there was a meaningful relationship between headmasters' perceptions of their own competency in using technology and leadership behaviours. Headmasters who received training in education technologies and use, also headmasters who felt more competent in using education technologies showed more leadership behaviours.

In the study carried out by Banoğlu [18] in Kadıköy and Maltepe districts in Istanbul to determine primary and secondary school administrators' technology leadership competencies, ISTE technology leadership standards were used [19]. These standards were translated into Turkish; an assessment tool was developed and administered to 134 school administrators. The study results showed that school administrators were sufficiently competent in terms of technology leadership. The lowest level of competency was found to be under the sub-dimension "leadership and vision".

Çakır [20] studied the integration of technology with a leadership point of view in secondary schools and examined the headmasters' roles in integrating technology in schools and responsibilities of computer teachers. A questionnaire was administered in the study of which the participants were 38 school administrators and 35 computer teachers working in Amasya city in Turkey. The results showed that administrators' attitudes were mostly positive, but there were some negative attitudes towards some elements. Also, it was specified that teachers were aware of Web 2.0 technology, but some participants stated that they were not planning to use such technologies in their classrooms. 
Görgülü found in his dissertation study that teachers thought school administrators showed technology leadership competencies most of the time (2.83). Also, teachers stated that school administrators exhibited behaviours stated in the sub-dimensions of technology leadership most of the time. Again, Görgülü determined that school administrators' perceptions towards technology leadership competencies were meaningfully higher compared to teachers' perceptions regarding school administrators' technology leadership and competencies [21].

Weng and Tang in their study [22] dwelled on four main themes regarding education administrators' technology leadership: (1) level of technology leadership adopted by administrators in primary schools, (2) level of school administration's awareness, (3) the relationship between administrators' technology leadership strategies and school administration's effectiveness, (4) whether school administration's effectiveness can be predicted via administrators' technology leadership strategies. The participants of the study were 332 administrators of 82 secondary schools in Taiwan and on the islands of the three seas. Semi-structured interviews, expert validity studies, and pilot study were conducted to develop the "Technology Leadership Strategies and School Administrative Effectiveness Scale". According to the results, it was found that primary school administrators were quite aware of using technology leadership strategies and their effectiveness levels in terms of school administration was high. The conclusion also showed that technology leadership strategies had positive effects on the effectiveness of school administration.

Titrek [23] examined headmasters' innovation management levels with 1436 participants from Istanbul, Kocaeli, and the Sakarya cities in Turkey. Titrek used the "Innovation Management Scale" of which the validity was previously done. In this study, a descriptive model was used to compare headmasters' characteristics such as gender, age, residence, and seniority with their innovation management levels. Positive differences were observed in favour of male participants with regard to gender. Furthermore, headmasters' innovation management levels were higher than teachers'.

Irmak [24] conducted a study to determine secondary and primary school teachers' and school administrators' perceptions level of technology leadership and reveal to what extent these roles affected their performances. In this context, population of the study was collected of 3933 teachers working in 139 primary and elementary schools in the Denizli city centre between 2012 and 2013. The study was done using a "Screening Model". A 5-point likert type scale with 29 items developed by Sincar [25] was used in this study and the study results showed that the teachers believed school administrators showed moderate technology leadership behaviours. Again, school administrators showed behaviours in the "anthropocentricism", "vision", "communication and cooperation" sub-dimensions moderately. They "Often" (Sufficiently) showed behaviours specified under "Support" sub-dimension.

\section{Research Objectives and Research Questions}

The aim of the study is to supply answers to the following questions:

Q1: Does the whole scale and all of its sub-dimensions weighted average scores of the administrators differ based on institution type?

Q2: Does the whole scale and all of its sub-dimensions weighted average scores of the administrators differ based on their positions?

Q3: Does the whole scale and all of its sub-dimensions weighted average scores of the administrators differ based on their years of seniority?

Q4: Does the whole scale and all of its sub-dimensions weighted average scores of the administrators differ based on gender?

Q5: Do the whole scale and all of its sub-dimensions weighted average scores of the administrators differ based on institutions' place?

\section{Materials and Methods}

This study aims to reveal education administrators' technology leadership competencies and variables affecting these competencies. A screening model was adopted and the sample for this study was composed of school administrators (headmaster, deputy head-manager and deputy manager) working at formal pre-schools, primary schools, secondary schools, high schools, vocational and technical high schools, counselling and research centres, teacherages, and public education centres located in the Çorum city centre between 2015 and 2016. Permission was obtained from the Çorum Provincial Directorate of National Education and the Çorum Governorate before the study was conducted. The sample data was collected from 161 school administrators from 526 institutions who completed the "Education Administrators' Technology Leadership Competencies" scale voluntarily. More information on the scale can be obtained from www.moodle.hitit.edu.tr/technology-leadership-of-school-a dministrators. Information regarding the participants is given in Table 1.

As it is seen in Table 1, 9 of the school administrators work in pre-school institutions, 59 of them work in primary schools, 49 of them work in secondary schools, 24 of them work in high schools, and 10 of them work in vocational and technical high schools. One hundred and twenty five of the school administrators are headmasters, 2 of them are deputy head-managers, and 34 are deputy managers. Fifteen of the administrators' year of seniority was between 1 and 8, 49 of the administrators' year of seniority was between 9 and 16 , 42 of the administrators' year of seniority was between 17 and 24, 46 of the administrators' year of seniority was 
between 25 and 32, and 9 of the administrators' year of seniority was 33 and above. One hundred and forty of the administrators were males and 21 of them were females.

The data collection tool was taken from "Developing and Reliability Study of "Education Administrators' Technology Leadership Competencies Scale" developed by Banoğlu [27] and the writer's permission was obtained. Reliability of the data collection tool was done and Cronbach's Alpha reliability co-efficient was found to be 0.943 . The data collection tool had 32 items to measure school administrators' technology leadership competencies. Descriptive statistics were used to analyze the items regarding personal information, received training on information technologies and using information technologies. The T-test and Levene test were used to identify the relationship between received training on information technologies, using information technologies and gender. One-way variance analysis (ANOVA) was used to identify the relationship between received training on information technologies, using information technologies and school type, professional seniority. However, firstly, the Levene test was administered for variance analysis and variance homogeneity was tested. When $\mathrm{p}$ was $<0.05$ in the Levene test (when variances were not homogeneous), the Kruskal Wallis- H Test was used. The Mann-Whitney U test was administered to determine the source of difference that emerged after the Kruskal Wallis- H Test.

As it is seen in Table 1, 9 of the school administrators work in pre-school institutions, 59 of them work in primary schools, 49 of them work in secondary schools, 24 of them work in high schools, and 10 of them work in vocational and technical high schools. One hundred and twenty five of the school administrators are headmasters, 2 of them are deputy head-managers, and 34 are deputy managers. Fifteen of the administrators' year of seniority was between 1 and 8,49 of the administrators' year of seniority was between 9 and 16 , 42 of the administrators' year of seniority was between 17 and 24, 46 of the administrators' year of seniority was between 25 and 32, and 9 of the administrators' year of seniority was 33 and above. One hundred and forty of the administrators were males and 21 of them were females.

Table 1. Information Regarding the Participants

\begin{tabular}{|c|c|c|c|}
\hline & & $\mathrm{N}$ & $\%$ \\
\hline \multirow{10}{*}{ Type of Institutions } & Primary School & 59 & 36.6 \\
\hline & Secondary School & 41 & 25.5 \\
\hline & Religious Vocational Secondary School & 8 & 5.0 \\
\hline & Anatolian High School & 22 & 13.7 \\
\hline & High School of Science & 2 & 1.2 \\
\hline & Vocational and Technical High School & 10 & 6.2 \\
\hline & Preschool & 9 & 5.6 \\
\hline & Public Education Centre & 2 & 1.2 \\
\hline & Teacherage & 1 & 0.6 \\
\hline & Other Institutions & 7 & 4.3 \\
\hline \multirow{3}{*}{ Type of Task } & School Manager & 125 & 77.6 \\
\hline & The Chief Deputy Principal & 2 & 1.2 \\
\hline & The Deputy Director & 34 & 21.1 \\
\hline \multirow{5}{*}{ Seniority } & $1-8$ & 15 & 9.2 \\
\hline & $9-16$ & 49 & 30.4 \\
\hline & $17-24$ & 42 & 26.2 \\
\hline & $25-32$ & 46 & 28.6 \\
\hline & $33+$ & 9 & 5.6 \\
\hline \multirow{5}{*}{ Age Ranges } & $27-34$ & 27 & 16.8 \\
\hline & $35-42$ & 49 & 30.4 \\
\hline & $43-50$ & 52 & 32.3 \\
\hline & $51-58$ & 26 & 16.0 \\
\hline & $59+$ & 7 & 4.3 \\
\hline \multirow{2}{*}{ Age } & Male & 140 & 87.0 \\
\hline & Female & 21 & 13.0 \\
\hline Total & & 161 & 100 \\
\hline
\end{tabular}


The data collection tool was taken from "Developing and Reliability Study of "Education Administrators' Technology Leadership Competencies Scale" developed by Banoğlu [27] and the writer's permission was obtained. Reliability of the data collection tool was done and Cronbach's Alpha reliability co-efficient was found to be 0.943 . The data collection tool had 32 items to measure school administrators' technology leadership competencies. Descriptive statistics were used to analyze the items regarding personal information, received training on information technologies and using information technologies. The Levene and T-test test were used to identify the relationship between received training on information technologies, using information technologies and gender. One-way variance analysis (ANOVA) was used to identify the relationship between received training on information technologies, using information technologies and school type, professional seniority. However, firstly, the Levene test was administered for variance analysis and variance homogeneity was tested. When $p$ was $<0.05$ in the Levene test (when variances were not homogeneous), the Kruskal Wallis- H Test was used. The Mann-Whitney U test was administered to determine the source of difference that emerged after the Kruskal Wallis- H Test.

\section{Findings}

Administrators' institutions were grouped by types. Accordingly, 11 groups were created: primary school, secondary school, Imam Hatip High School, Anatolian High School, Health High School, Pre-school, Public Education Centre, Teacherage, and others.

The Levene test was administered to find whether variances among these groups were equal or not and the results can be seen in Table 2. According to these results, variances were not homogenous $(\mathrm{F}=3.179 ; \mathrm{p}<.05)$.

It was found that administrators of teacherages scored highest from the whole technology leadership scale regarding weighted average $(X=4.56)$ and while administrators of pre-schools scored lowest $(X=3.99)$, administrators teacher's house scored highest $(X=4.56)$. Other sub-dimensions and weighted averages can be seen in Table 3.

Table 2. Homogeneity of Variances Test Scores

\begin{tabular}{ccccc}
\hline Levene Statistic & df1 & df2 & Sig. \\
3.179 & 3 & 77 & .029 \\
\hline
\end{tabular}

Table 3. Weighted Average Scores of the Whole Scale and its Sub-dimensions by Institution Type

\begin{tabular}{|c|c|c|c|c|c|c|}
\hline Type of School & $\begin{array}{l}\text { Visionary } \\
\text { Leadership }\end{array}$ & $\begin{array}{l}\text { Digital-age } \\
\text { Learning Culture }\end{array}$ & $\begin{array}{c}\text { Excellence in } \\
\text { Professional } \\
\text { Development }\end{array}$ & $\begin{array}{c}\text { Systemic } \\
\text { Improvement }\end{array}$ & $\begin{array}{c}\text { Digital } \\
\text { Citizenship }\end{array}$ & All Sizes \\
\hline Primary School & 3.9138 & 4.0621 & 3.8750 & 3.6497 & 4.2712 & 3.9603 \\
\hline Secondary School & 3.7785 & 4.0569 & 3.8506 & 3.5366 & 4.2927 & 3.8963 \\
\hline Religious Vocational Secondary School & 4.1146 & 4.2083 & 4.2031 & 3.6250 & 4.5625 & 4.1836 \\
\hline Anatolian High School & 3.9130 & 4.1884 & 3.9674 & 3.7101 & 4.2536 & 3.9973 \\
\hline High School of Science & 3.9583 & 4.5000 & 4.0000 & 3.8333 & 4.4167 & 4.0938 \\
\hline Vocational and Technical High School & 3.5417 & 3.8000 & 3.5750 & 3.3333 & 4.2167 & 3.6813 \\
\hline Preschool & 3.4722 & 3.7037 & 3.6250 & 3.0741 & 3.7778 & 3.5521 \\
\hline Public Education Centre & 3.9583 & 4.1667 & 4.0000 & 4.3333 & 4.2500 & 4.0781 \\
\hline Teacherage & 4.7500 & 4.0000 & 4.5000 & 4.3333 & 4.6667 & 4.5625 \\
\hline Other Institutions & 3.7024 & 3.8571 & 3.6786 & 3.6667 & 3.8571 & 3.7366 \\
\hline Total & 3.8390 & 4.0473 & 3.8642 & 3.5926 & 4.2438 & 3.9176 \\
\hline
\end{tabular}


Table 4. ANOVA Results of the Weighted Average Scores of the Whole Scale and Sub-dimensions by Institution Type

\begin{tabular}{|c|c|c|c|c|c|c|}
\hline & Source of Variance & Sum of Squares & df & Mean Square & $\mathrm{F}$ & Sig. \\
\hline \multirow{3}{*}{ Visionary Leadership } & Between Groups & 4.327 & 9 & .481 & 1.033 & .416 \\
\hline & Within Groups & 70.717 & 152 & .465 & & \\
\hline & Total & 75.043 & 161 & & & \\
\hline \multirow{3}{*}{ Digital-age Learning Culture } & Between Groups & 3.050 & 9 & .339 & .567 & .823 \\
\hline & Within Groups & 90.920 & 152 & .598 & & \\
\hline & Total & 93.971 & 161 & & & \\
\hline \multirow{3}{*}{$\begin{array}{l}\text { Excellence in Professional } \\
\text { Development }\end{array}$} & Between Groups & 3.249 & 9 & .361 & .637 & .764 \\
\hline & Within Groups & 86.107 & 152 & .566 & & \\
\hline & Total & 89.356 & 161 & & & \\
\hline \multirow{3}{*}{ Systemic Improvement } & Between Groups & 5.540 & 9 & .616 & .641 & .761 \\
\hline & Within Groups & 146.016 & 152 & .961 & & \\
\hline & Total & 151.556 & 161 & & & \\
\hline \multirow{3}{*}{ Digital Citizenship } & Between Groups & 4.204 & 9 & .467 & 1.089 & .374 \\
\hline & Within Groups & 65.192 & 152 & .429 & & \\
\hline & Total & 69.397 & 161 & & & \\
\hline \multirow{3}{*}{ All Sizes } & Between Groups & 3.358 & 9 & .373 & 0.889 & .537 \\
\hline & Within Groups & 63.802 & 152 & .420 & & \\
\hline & Total & 67.160 & 161 & & & \\
\hline
\end{tabular}

Table 4 shows that there was no difference between scores the administrators obtained from the whole scale and its sub-dimensions by institution type. In other words, administrators' technology leadership and its sub-dimension leadership scores do not differ by institution type.

Table 5. Weighted Average Scores of the Whole Scale and its Sub-dimensions by Administrators' Positions

\begin{tabular}{|c|c|c|c|c|c|c|}
\hline & $\begin{array}{l}\text { Visionary } \\
\text { Leadership }\end{array}$ & $\begin{array}{c}\text { Digital-age } \\
\text { Learning Culture }\end{array}$ & $\begin{array}{l}\text { Excellence in } \\
\text { Professional } \\
\text { Development }\end{array}$ & $\begin{array}{c}\text { Systemic } \\
\text { Improvement }\end{array}$ & $\begin{array}{c}\text { Digital } \\
\text { Citizenship }\end{array}$ & All Sizes \\
\hline School Manager & 3.8300 & 4.0850 & 3.9080 & 3.6267 & 4.2640 & 3.9373 \\
\hline The Chief Deputy Principal & 4.0800 & 4.1660 & 3.8750 & 4.0000 & 4.3333 & 4.0781 \\
\hline The Deputy Director & 3.8400 & 3.9040 & 3.7071 & 3.4476 & 4.1667 & 3.8384 \\
\hline Total & 3.8390 & 4.0470 & 3.8642 & 3.5926 & 4.2438 & 3.9176 \\
\hline
\end{tabular}

According to Table 5, deputy head-managers scored highest in the "Visionary Leadership, Digital Learning Culture, Systematic Development, and Digital Citizenship" sub-dimensions and the Whole scale. Headmasters had the highest weighted average scores in Perfection in the Professional Development sub-dimension. 
Tablo 6. ANOVA Results of the Weighted Average Scores of the Whole Scale and its Sub-dimensions by Administrators' Positions

\begin{tabular}{|c|c|c|c|c|c|c|}
\hline & Source of Variance & Sum of Squares & df & Mean Square & $\mathrm{F}$ & Sig. \\
\hline \multirow{3}{*}{ Visionary Leadership } & Between Groups & 0.123 & 2 & 0.062 & 0.131 & 0.878 \\
\hline & Within Groups & 74.92 & 159 & 0.471 & & \\
\hline & Total & 75.043 & 161 & & & \\
\hline \multirow{3}{*}{ Digital-age Learning Culture } & Between Groups & 0.319 & 2 & 0.16 & 0.38 & 0.685 \\
\hline & Within Groups & 66.84 & 159 & 0.42 & & \\
\hline & Total & 67.16 & 161 & & & \\
\hline \multirow{3}{*}{$\begin{array}{l}\text { Excellence in Professional } \\
\text { Development }\end{array}$} & Between Groups & 0.92 & 2 & 0.46 & 0.786 & 0.457 \\
\hline & Within Groups & 93.05 & 159 & 0.585 & & \\
\hline & Total & 93.971 & 161 & & & \\
\hline \multirow{3}{*}{ Systemic Improvement } & Between Groups & 1.103 & 2 & 0.552 & 0.994 & 0.372 \\
\hline & Within Groups & 88.253 & 159 & 0.555 & & \\
\hline & Total & 89.356 & 161 & & & \\
\hline \multirow{3}{*}{ Digital Citizenship } & Between Groups & 1.213 & 2 & 0.606 & 0.641 & 0.528 \\
\hline & Within Groups & 150.343 & 159 & 0.946 & & \\
\hline & Total & 151.556 & 161 & & & \\
\hline \multirow{3}{*}{ All Sizes } & Between Groups & 0.275 & 2 & 0.138 & 0.317 & 0.729 \\
\hline & Within Groups & 69.121 & 159 & 0.435 & & \\
\hline & Total & 69.397 & 161 & & & \\
\hline
\end{tabular}

The Analyzed results presented in Table 6 show that there was no difference between scores the administrators obtained from the whole scale and its sub-dimensions by their positions. That is, administrators' technology leadership and its sub-dimension leadership scores do not differ by positions type.

Table 7. Weighted Average Scores of the Whole Scale and its Sub-dimensions by Administrators' Years of Seniority

\begin{tabular}{ccccccc}
\hline Seniority & $\begin{array}{c}\text { Visionary } \\
\text { Leadership }\end{array}$ & $\begin{array}{c}\text { Digital-age } \\
\text { Learning Culture }\end{array}$ & $\begin{array}{c}\text { Excellence in } \\
\text { Professional } \\
\text { Development }\end{array}$ & $\begin{array}{c}\text { Systemic } \\
\text { Improvement }\end{array}$ & Digital Citizenship & All Sizes \\
\hline $1-8$ & 3.46 & 3.90 & 3.60 & 3.10 & 4.14 & 3.63 \\
$9-16$ & 3.46 & 3.90 & 3.61 & 3.10 & 3.24 & 4.13 \\
$17-24$ & 3.68 & 3.97 & 3.68 & 3.40 & 4.33 & 4.76 \\
$25-32$ & 3.98 & 4.16 & 4.02 & 4.00 & 4.56 & 4.27 \\
$33+$ & 4.22 & 4.26 & 4.25 & & 4.06 & \\
\hline
\end{tabular}

When Table 7 is examined, it is seen that participants working as administrators for 33 years and more scored highest in the Whole scale and its sub-dimensions. This means that participants working as administrators for 33 years and more scored highest in technology use leadership average scores and its sub-dimensions "Visionary Leadership, Digital Learning Culture, Perfection in Professional Development, Systematic Development, and Digital Citizenship".

Table 8. Homogeneity Test of the Variances

\begin{tabular}{lcccc}
\hline Factor & Levene Statistic & df1 & df2 & S \\
\hline Digital Citizenship & 1.228 & 4 & 157 & 0 \\
Visionary Leadership & 1.361 & 4 & 157 & 0 \\
Digital-age Learning Culture & 1.045 & 4 & 157 & 0 \\
Excellence in Professional Development & 1.298 & 4 & 157 & 0 \\
Systemic Improvement & 1.898 & 4 & 157 & 0 \\
All Sizes & 1.211 & 4 & 157 & 0 \\
\hline
\end{tabular}

The Levene test results done to check homogeneity among variances can be seen in Table 8 . Accordingly, all variances were homogeneous; that is, equal $(\mathrm{p}>.05)$ 
Table 9. ANOVA Results of the Weighted Average Scores of the Whole Scale and Sub-dimensions by Administrators' Years of Seniority

\begin{tabular}{llccccc}
\hline & Source of Variance & Sum of Squares & df & Mean Square & F & Sig. \\
\hline \multirow{2}{*}{ Visionary Leadership } & Between Groups & 5.721 & 4 & 1.430 & 3.239 & .014 \\
& Within Groups & 69.323 & 157 & .442 & & \\
& Total & 75.043 & 161 & & & \\
& Between Groups & 1.648 & 4 & .412 & .700 & .593 \\
Digital-age Learning Culture & Within Groups & 92.323 & 157 & .588 & & \\
& Total & 93.971 & 161 & & & \\
Excellence in Professional Development & Between Groups & 5.152 & 4 & 1.288 & 2.402 & .050 \\
& Within Groups & 84.204 & 157 & .536 & & \\
& Total & 89.356 & 161 & & & \\
Systemic Improvement & Between Groups & 10.646 & 4 & 2.662 & 2.966 & .021 \\
& Within Groups & 140.909 & 157 & .898 & & \\
& Total & 151.556 & 161 & & & \\
& Between Groups & 1.939 & 4 & 0.485 & 1.128 & .345 \\
& Within Groups & 67.458 & 157 & .430 & & \\
Digital Citizenship & Total & 69.397 & 161 & & & \\
& Between Groups & 4.458 & 4 & 1.115 & 2.791 & .028 \\
& Within Groups & 62.702 & 157 & .399 & & \\
& Total & 67.160 & 161 & & & \\
\hline
\end{tabular}

Table 9 shows the ANOVA test results of the Whole scale and sub-dimensions scores by administrators' years of seniority. There was not a meaningful difference between digital era learning culture, digital citizenship and years of seniority ( $p>05$ ). It was also seen that there was a meaningful difference between technology leadership scores and the weighted average scores obtained from visionary leadership, perfection in professional development, and systematic development sub-dimensions $(\mathrm{p}<=.05)$. Administrators' technology leadership, visionary leadership, perfection in professional development and systematic development scores differ by year of seniority.

Table 10. Weighted Average Scores of the Whole Scale and Sub-dimensions by Administrators' Ages

\begin{tabular}{|c|c|c|c|c|c|c|}
\hline Age & $\begin{array}{l}\text { Visionary } \\
\text { Leadership }\end{array}$ & $\begin{array}{c}\text { Digital-age } \\
\text { Learning Culture }\end{array}$ & $\begin{array}{l}\text { Excellence in } \\
\text { Professional } \\
\text { Development }\end{array}$ & $\begin{array}{c}\text { Systemic } \\
\text { Improvement }\end{array}$ & Digital Citizenship & All Sizes \\
\hline $27-34$ & 3.72 & 4.05 & 3.85 & 3.52 & 4.25 & 3.86 \\
\hline $35-42$ & 3.75 & 3.95 & 3.75 & 3.45 & 4.16 & 3.82 \\
\hline $43-50$ & 3.86 & 4.01 & 3.82 & 3.56 & 4.21 & 3.90 \\
\hline $51-58$ & 3.98 & 4.23 & 4.09 & 3.91 & 4.38 & 4.10 \\
\hline $59+$ & 4.23 & 4.29 & 4.18 & 3.95 & 4.50 & 4.25 \\
\hline
\end{tabular}

According to Table 10, the administrators aged 59 and above scored highest in the Whole scale and its sub-dimensions. Technology use leadership average scores and visionary leadership, digital era learning culture, perfection in professional development, systematic development, and digital citizenship scores of the administrators aged 59 and above were highest. This result overlaps with the weighted averages scores by year of seniority.

Table 11. Homogeneity Test of Variances

\begin{tabular}{lcccc}
\hline Factor & Levene Statistic & df1 & df2 & Sig. \\
\hline Digital Citizenship & & 4 & 157 & 0.287 \\
Visionary Leadership & 1.524 & 4 & 157 & 0.198 \\
Digital-age Learning Culture & 1.732 & 4 & 157 & 0.146 \\
Excellence in Professional Development & 1.128 & 4 & 157 & 0.346 \\
Systemic Improvement & 2.806 & 4 & 157 & 0.068 \\
All Sizes & 1.262 & 4 & 157 & 0.388 \\
\hline
\end{tabular}

The Levene test results done to check homogeneity among variances can be seen in Table 11. Accordingly, all variances were homogeneous; that is, equal ( $\mathrm{p}>.05)$. 
Table 12. ANOVA Results of the Weighted Average Scores of the Whole Scale and Sub-dimensions by Administrators' Ages

\begin{tabular}{|c|c|c|c|c|c|c|}
\hline & Source of Variance & Sum of Squares & df & Mean Square & $\mathrm{F}$ & Sig. \\
\hline \multirow{4}{*}{ Visionary Leadership } & Between Groups & 2.371 & 4 & .593 & 1.281 & .280 \\
\hline & Within Groups & 72.672 & 157 & .463 & & \\
\hline & Total & 75.043 & 161 & & & \\
\hline & Between Groups & 1.776 & 4 & .444 & .756 & .555 \\
\hline \multirow[t]{2}{*}{ Digital-age Learning Culture } & Within Groups & 92.164 & 157 & .587 & & \\
\hline & Total & 93.971 & 161 & & & \\
\hline \multirow{3}{*}{$\begin{array}{c}\text { Excellence in Professional } \\
\text { Development }\end{array}$} & Between Groups & 2.687 & 4 & .672 & 1.217 & .306 \\
\hline & Within Groups & 86.669 & 157 & .552 & & \\
\hline & Total & 89.356 & 161 & & & \\
\hline \multirow{3}{*}{ Systemic Improvement } & Between Groups & 4.711 & 4 & 1.178 & 1.259 & .288 \\
\hline & Within Groups & 146.845 & 157 & .935 & & \\
\hline & Total & 151.556 & 161 & & & \\
\hline \multirow{3}{*}{ Digital Citizenship } & Between Groups & 1.343 & 4 & .336 & .775 & .543 \\
\hline & Within Groups & 68.054 & 157 & .433 & & \\
\hline & Total & 69.397 & 161 & & & \\
\hline
\end{tabular}

According to the analysis results shown in Table 12, there was not a difference between administrators' scores from the Whole scale and sub-dimensions and their ages. That is, administrators' technology leadership and sub-dimension leadership scores do not differ by their ages.

Table 13. T-Test Results of the Weighted Average Scores of the Whole Scale and Sub-dimensions by Gender

\begin{tabular}{|c|c|c|c|c|c|c|c|}
\hline Factor & Age & $\mathrm{N}$ & $\mathrm{X}$ & Std. Dev. & $\mathrm{df}$ & $\mathrm{t}$ & $\mathrm{p}$ \\
\hline \multirow{2}{*}{ All Sizes } & Male & 140 & 3.92 & 0.66 & 160 & 0.111 & 0.912 \\
\hline & Female & 21 & 3.90 & 0.54 & & & \\
\hline \multirow{2}{*}{ Visionary Leadership } & Male & 140 & 3.84 & 0.69 & 160 & 0.042 & 0.967 \\
\hline & Female & 21 & 3.83 & 0.62 & & & \\
\hline \multirow{2}{*}{ Digital-age Learning Culture } & Male & 140 & 4.04 & 0.78 & 160 & 0.287 & 0.774 \\
\hline & Female & 21 & 4.09 & 0.65 & & & \\
\hline \multirow{2}{*}{$\begin{array}{l}\text { Excellence in Professional } \\
\text { Development }\end{array}$} & Male & 140 & 3.85 & 0.76 & 160 & 0.495 & 0.621 \\
\hline & Female & 21 & 3.94 & 0.62 & & & \\
\hline \multirow{2}{*}{ Systemic Improvement } & Male & 140 & 3.61 & 0.98 & 160 & 0.717 & 0.750 \\
\hline & Female & 21 & 3.45 & 0.91 & & & \\
\hline \multirow{2}{*}{ Digital Citizenship } & Male & 140 & 4.26 & 0.68 & 160 & 0.883 & 0.095 \\
\hline & Female & 21 & 4.13 & 0.52 & & & \\
\hline
\end{tabular}

Table 13 shows that gender has no effect on technology leadership total scores and sub-dimensions scores. Also, weighted average scores of males $(X=3.92)$ were slightly higher than females' scores $(X=3.90)$. Both genders had the same average scores in visionary leadership, but females had the highest average scores in digital age learning $(X=4.09)$ and perfection in professional development $(X=3.94)$, whereas males had the highest average scores in systematic development $(X=3.61)$ and digital citizenship $(X=4.26)$. 
Table 14. T-Test Results of the Weighted Average Scores of the Whole Scale and Sub-dimensions by Institutions' Place

\begin{tabular}{|c|c|c|c|c|c|c|c|}
\hline Factor & Hometown & $\mathrm{N}$ & $\mathrm{X}$ & Std. Dev. & df & $\mathrm{t}$ & $\mathrm{p}$ \\
\hline \multirow{2}{*}{ All Sizes } & City & 98 & 3.87 & 0.65 & 160 & 1.1 & 0.275 \\
\hline & County & 63 & 3.99 & 0.65 & & & \\
\hline \multirow{2}{*}{ Visionary Leadership } & City & 98 & 3.80 & 0.68 & 160 & 0.84 & 0.404 \\
\hline & County & 63 & 3.89 & 0.7 & & & \\
\hline \multirow{2}{*}{ Digital-age Learning Culture } & City & 98 & 3.96 & 0.76 & 160 & 1.83 & 0.069 \\
\hline & County & 63 & 4.18 & 0.76 & & & \\
\hline \multirow{2}{*}{ Excellence in Professional Development } & City & 98 & 3.84 & 0.76 & 160 & 0.58 & 0.563 \\
\hline & County & 63 & 3.90 & 0.72 & & & \\
\hline \multirow{2}{*}{ Systemic Improvement } & City & 98 & 3.53 & 0.94 & 160 & 0.95 & 0.343 \\
\hline & County & 63 & 3.68 & 1.01 & & & \\
\hline \multirow{2}{*}{ Digital Citizenship } & City & 98 & 4.18 & 0.67 & 160 & 1.37 & 0.174 \\
\hline & County & 63 & 4.33 & 0.63 & & & \\
\hline
\end{tabular}

According to Table 14, institutions' place had no effect on technology leadership total scores and its sub-dimensions' scores. Interestingly though, administrators' weighted average scores obtained from the Whole scale and its sub-dimensions are higher in districts. This may stem from the fact that younger administrators with shorter position terms work in these districts. It may be thought that younger administrators have high levels of technology literacy and technology leadership skills.

When the other studies are examined, according to seniority years of school administrator technology leadership self-efficacy and sub-dimensions of this self-efficacy were found to be high. Particularly it shows that significant differences happen to participation in IT in-service programs [26].

\section{Conclusion}

The findings obtained from the analysis of the "Education Administrators Technology Leadership" scale developed by Banoğlu [27] are interpreted in this section. Technology leadership competency scores of pre-schools were lower compared to the other school types. This may indicate that these schools' needs are less when students' age levels and schools' technological needs are considered.

Scores by positions types are positive when the Whole scale and its sub-dimension scores are examined. It is striking that headmasters scores were higher in "perfection in professional development" sub-dimension. "Perfection in professional development" is defined as "Through contemporary technology and digital tools, education administrator creates an environment to enable professional development of teachers to develop learners' learning"[27]. In this sense, it is an expected result for headmasters to score higher in this sub-dimension.
The findings show that there was a meaningful difference between the period of office and "visionary leadership, perfection in professional development, and systematic development" sub-dimensions. Besides, all sub-dimensions of the scale and the period of office increased or decreased in the same direction. It can be said that professional experiences of administrators affects their technology competencies positively.

When the literature is examined, it is seen that administrators knowledgeable with information technology and technology training have better technology competencies. Therefore, it is suggested that thanks to in-service technology trainings given to school administrators, they will possess better technology leadership and competency levels. Also, since technology competency is directly proportionate to year of seniority and age, young administrators and senior administrators should gather in various activities and thus, they will be able to share their knowledge of technology competency in schools.

\section{Note}

*The abstract of this paper was presented at 2nd International Conference on Lifelong Learning and Leadership for All (ICLEL-16), in Liepaja on July, 21-23, 2016.

\section{REFERENCES}

[1] ITEA (2007). Standards for Technological Literacy: Content for the Study of Technology. International Technology Education Association and Its Technology for All American Project. Reston, Virginia: ITEA, 
fromhttp://www.iteea.org/TAA/PDFs/xstnd.pdf, Access Date: August 2015.

[2] Çoklar, A.N. \& Şahin, Y.G. Technology Literacy According to Students: What is It, Where are we and What Should We Do for Parents and Children? Turkish Online Journal of Qualitative Inquiry. 2014:5(2); 27-34.

[3] The Colorado Department of Education (CDE). What is Technology Literacy? Professional Development Module 1. Technology Literacy Assessment Project (TLAP) Professional Development Modules, Longmont: from https://www.coloradotechliteracy.org/org/documentation/ module1, Access Date: 18.08.2015.

[4] Dağ, F. Examination of the professional development studies for the development of technological competence of teachers in Turkey in the context of lifelong learning, International Journal of Human Sciences. 2016: 13(1); 90-111.

[5] Odabaşı, F. Toplumsal Etkiler ve Teknoloji Okuryazarlı̆̆ı. Education Conference In light of Information Technology (BITE 2000) in Middle East Technical University. Ankara, May 15-17, 2000.

[6] Finn, J. D. Technology and the instructional process. Audiovisual Communication Review. 1960:8(1); 9-10.

[7] https://en.wikipedia.org/wiki/Educational_technology, Access Date: 06.06.2016.

[8] Volti, R. Society and technological change (5th ed.). New York: Worth.2006.

[9] McDermott, J. Technology: The opiate of intellectuals. In A.H. Teich (Ed.), Technology and man's future. New York: St. Martin's Press, 1981.

[10] Simon, Y. R. Pursuit of happiness and lust for power in technological society. In C. Mitcham \& R. Mackey (Eds.). Philosophy and Technology. New York: Free Press, 1983.

[11] Özkul, A. E. ve Girginer, N. Uzaktan eğitimde teknoloji ve etkinlik. I. Uluslararası Eğitim Teknolojileri Sempozyumunda sunulan bildiri. Sakarya, 2001.

[12] Valdez, G. (2004). Critical issue: Technology leadership: Enhancing positive educational change. http://www.ncrel.org/sdrs/areas/issues/educatrs/leadrshp/le7 00.htm, Access date: February 2016.

[13] Brooks-Young, S. Making technology standards work for you: A guide for school administrators. ISTE Publications, 2002, From http://books.google.com.tr/ books? id=2VHe01tWQgcC\&printsec $=$ frontcover\#v= onepage $\& \mathrm{q}=\& \mathrm{f}=$ false, Access date: August 8, 2015.

[14] Weber, M. J. Study of computer technology use and technology leadership of Texas elementary public school principals. Unpublished doctoral dissertation, University of North Texas, 2006. From http://wwwlib.umi.com/dissertatio ns/preview/3214502, Access date: June 2015.

[15] Schrum, L. Advancing the field: considering acceptable evidence in educational technology research. Contemporary Issues in Technology and Teacher Education - CITE. 2005:5(3/4). From

http://www.citejournal.org/vol5/iss3/editorial/article1.cfm, April 2015.

[16] Ertmer, P. A., Bai, H., Dong, C., Khalil, M., Park, S. H., \& Wang, L. Technology leadership: Shaping administrators' knowledge and skills through an online professional development course, 2002. From http://www.edci.purdue.edu/ertmer/docs/SITE02 TIPDOC paper.PDF, Access date: February 2016.

[17] Şişman-Eren, E. İlköğretim okul müdürlerinin eğitim teknolojilerini sağlama vekullanmada gösterdikleri liderlik davranışları. Yayımlanmış Doktora Tezi, Anadolu Üniversitesi Eğitim Bilimleri Enstitüsü, Eskişehir, 2010.

[18] Banoğlu, K. School Principals' Technology Leadership Competency and Technology Coordinatorship, Educational Sciences: Theory \& Practice, 2011:11(1); 208-213.

[19] Technology Leadership: Shaping Administrators' Knowledge and Skills through an Online Professional Development Course. From http://www.iste.org/ images/excerpts/TLPREP-excerpt.pdf Access date: February 2015 .

[20] Çakır, R. (2012), Technology Integration and Technology Leadership in Schools as Learning Organizations, the Turkish Online Journal of Educational. 2012:11(4);273-282.

[21] Görgülü, D. Bilgi Toplumuna Geçiş Sürecinde Okul Yöneticilerinin Teknolojik Liderlik Yeterlilikleri Açısından İncelenmesi (Konya İli Örneği), Master Thesis, Atatürk Ünversitersi, Erzurum, 2013.

[22] Weng, C.H., Tang, Y. The relationship between technology leadership strategies and effectiveness of school administration: An empirical study. Computers \& Education, 2014:76; 91-107.

[23] Titrek, O. The Level of Innovation Management of School Principals' in Turkey, Anthropologist. 2015:19(2);449-456.

[24] Irmak, M. İlkokul ve ortaokul öğretmenlerinin, yöneticilerinin "teknoloji liderliği” düzeylerine ilişkin algıları, Yüksek Lisans Tezi, Pamukkale Üniversitesi, Denizli, 2015.

[25] Sincar, M. İlköğretim okulu yöneticilerinin teknoloji liderliği yeterliliklerine ilişkin bir inceleme (Gaziantep ili örneği). Yayımlanmamış Doktora Tezi, İnönü Üniversitesi Sosyal Bilimler Enstitüsü, Malatya, 2009.

[26] Ünal, E., Uzun, A.M., Karatas, S., An Examination of School Administrators' Technology Leadership Self-Efficacy, Croatian Journal of Education-Hrvatski Casopis Za Odgoj I Obrazovanje, 2015:17(1);195-215.

[27] Banoğlu, K. "Eğitim Yöneticilerinin Teknoloji Liderliği Yeterlilikleri Ölçeğinin" Geliştirilmesi ve Güvenilirlik Çalışması, İnönü Üniversitesi Eğitim Fakültesi Dergisi. 2012:13(3); 43-65. 